\title{
Innovation In Learning Through Digital Literacy at Vocational School of Health
}

\author{
Yasser Aabdul Djawad, Sutarsi Suhaeb, Hendra Jaya \\ Electronic Engineering Education Department, Engineering Faculty \\ Universitas Negeri Makassar \\ Makassar, Indonesia \\ yasserpdb@gmail.com
}

\begin{abstract}
This study aims to facilitate learning, therefore all existing technologies and educational technology products must be selected and built on the needs analysis of a particular learning environment. E-health learning media is an Androidbased Application. As we know that Android is one of the most widely used mobile platforms in the world with operating system based on open source. E-Health or Electronic Health is the use of information and communication technologies including electronics, telecommunications, computers and informatics to process various types of medical information, to perform clinical services (diagnosis or therapy), administration and education. As an education provider in the field of health, Vocational School of Health (SMK Kesehatan) feels obliged to participate in equipping their graduates with life skills in integrity, which combine generic and specific potency, to solve and overcome life problem. Life skills possessed by each graduate will include: Personal Knowledge, Rational Thinking Skills (Vocational Skills) and Vocational Skills. Implementation of digital literacy in SMK is expected to encourage students. One of the learning media that can be used through digital literacy is through the utilization of Androidbased applications. Results of Media Assessment of E-health application obtained average score 4.47 (Very Good).
\end{abstract} school

Keywords - learning, digital literacy, health vocational

\section{INTRODUCTION}

Indonesia is a developing country; the availability of technological infrastructure is still very minimal resulting in everyone to get information and knowledge to be limited. In the world of education in Indonesia, technological developments began to feel a positive impact, at this time distance and time is not a barrier to acquire knowledge. Information and Communication Technology as part of science and technology in general are all technologies related to the collection, collection, processing, storage, dissemination and presentation of information. With the existence of information and communication technology can make it easier to learn and get information needed from anywhere, anytime, and anywhere, various applications have been created to facilitate teaching and learning activities. Technology in education is a must in today's era. The development and widespread use of the internet provides many benefits to life not least the education world. There have been many technology-based tools that have been used in education such as powerpoint tools, educational videos, and multimedia products both conventional and interactive. In addition, with the development of mobile technology is also developing mobile multimedia that can facilitate mobile learning so someone can learn anywhere because learning resources can be obtained easily. The use of technology in learning must be tailored to the needs of the environment or where the learning process takes place. With appropriate technology, the function of technology as a learning facility can achieve the goal of improving learning performance.

The technology used in education aims to facilitate learning, therefore all existing technologies and educational technology products produced must be selected and built on the needs analysis of a particular learning environment. All elements and learning objectives must be determined to see it as a whole, so that the learning objectives to be achieved can be fulfilled.

The development of technology and information has led the present generation into the world of digital literacy. Digital literacy has become familiar, both in academics and non-academics. The emerging digital era is expected to spur school residents to utilize digital literacy in the academic field. One advantage that can be taken from the digital era is the school residents can access up to date educational information. This activity can be done by utilizing digital media, such as computers, laptops, or Smartphone connected to the Internet network that can be easily accessed by the citizens of the school. Nevertheless, the lack of knowledge about digital literacy becomes a serious obstacle in its application. One effort that can be done is to equip the citizens of schools with digital literacy capabilities to digitally dig up the information digitally [1]

Implementation of digital literacy in a School Literacy Movement needs to be adjusted in a structured learning process, or at least integrated with the learning process [2]. The goal is to have supervision in the use of digital media. This skill should be accommodated in the classroom as well as the school environment, so it should be maximally utilized for cognitive, social, linguistic, visual, and spiritual skills. With the implementation of digital literacy in the school Literacy movement, it is expected to give more benefits for students, especially learners to be able to spread ideas and find sources of information that can be accounted for. In addition, the use of digital literacy is believed to provide innovative learning. Innovation generally conducted by public organizations including educational institutions is through the utilization of Information Technology. This is because in the era of globalization as now the development and progress of Information Technology has been running 
very rapidly. Most schools, including Vocational High School, are innovating through the use of Information Technology such as the use of computers and laptops, LCD monitor facilities in the classroom, and the most popular now is using internet access as a supporter of the learning process. A good vocational education is responsive and anti spatial to the advancement of information technology [3].

Some schools in Makassar that have made innovations by utilizing Information Technology (IT) as an effort to improve the quality of education. This school has scored some glorious achievements especially in IT. One of them is the achievement of the first winner in Student Competency (LKS) SMK in South Sulawesi. Do not rule out the use of Information Technology is increasingly developed in Vocational School of Health can produce many other achievements. To that end the school should be developed and provided innovation in the form of provision of IT-based education facilities, professional human resource preparation, and cooperation made with the industrial world. Today we are on the verge of an Industrial revolution that will fundamentally change the way we live, work, and relate to each other. In its scale, scope, and complexity, the transformation that is taking place is different from what has been experienced by human beings before. We do not yet know exactly what will happen in the future. But one thing is clear: the world must respond to these changes in an integrated and comprehensive way by involving all global political stakeholders, from the public and private sectors, to academia, and, of course, civil society. Among the various sectors affected by the Fourth Industrial Revolution (4.0), it seems that the health sector is the sector most likely to benefit from the joining of physics, digital and biological systems, although this sector may also be the least prepared to accept it[4]. A poll of business leaders indicates that a significant majority of executives surveyed believe that health is a sector that will benefit greatly from the impact of this fourth Industrial Revolution (4.0). Today's consumer technology that uses mobile phones and daily fitness tools can gather detailed data about one's health and fitness status. Such data have the potential to transform not only individual health and medical needs, but also for health research. Many healthcare providers are exploring the potential of telemedicine, which is a remote monitoring and treatment of patients via internet-connected sensors. It is hoped that telemedicine will prove invaluable in the treatment of many chronic diseases experienced by the elderly. Going forward, it is highly possible that senior citizens receive medical check-ups with comfort even in their own homes. Telemedicine can also bring medical care to people in remote locations. In the future, some great medical applications emerge from a combination of physical, digital and biological technologies including pills that incorporate digital sensors to regulate drug release; limbs that respond to the patient's mind; as well as virtual reality psychotherapy. Globally, all these technologies are expected by many to have a major health impact, just as when the use of statistics was applied to all other disciplines in the late nineteenth century. Of course, a profound revolution will likely force healthcare providers to substantially adapt their work practices. Unfortunately, the EU poll also revealed that less than half of health executives (38\%) believe they are either 'enough' or 'very' ready for the Fourth Industrial Revolution. The results of this poll suggest that healthcare providers need to step up their efforts to integrate Industry 4.0 into their habits of life. Thus it takes an innovation form of school based on Information Technology in improving the quality of vocational education especially in the field of health, need to look for supporting factors and obstacles application of school innovation based on Information Technology in improving the quality of vocational education in health field. Educational innovation is innovation in education or innovation to solve problems in education [5], Meanwhile, according to[6] suggests there are several stages of the direction of educational innovation objectives in Indonesia, namely: 1) Pursuing all the backwardness generated by the progress of science and technology so that the longer education in Indonesia increasingly running parallel to the progress; Ensuring the implementation of school education and outside school for every citizen, for example in increasing the capacity of elementary school age, junior high, high school, and college.

\section{Digital Literation Movement In Vocational SCHOOL OF HEALTH}

\section{A. Literacy Movement}

School literacy movement has been initiated by Indonesia Ministry of Education and Culture (Kemendikbud) in 2015. This program is expected to improve the quality of human resources through a critical, analytical, and reflective information understanding culture [7]. This movement is implemented as an effort to foster the spirit of reading among students. Literation itself is interpreted as the ability to access, understand, and use something intelligently through various activities, such as reading, listening, writing, and speaking.

The term digital literacy is often referred to as a medium developed by information technology. The digital term in question is Digital Literacy is the interests, attitudes and abilities of individuals who use digital technology and communication tools to access, manage, integrate, analyze and evaluate information, build new knowledge, create and communicate with others in order to participate effectively in community.

The term digital literacy became popular around 2005 [8]. Digital literacy means the ability to connect to hyper textual information in the sense of computer-assisted unread reading. The term digital literacy was once used in the 1980s, (Davis \& Shaw, 2011), in general meaning the ability to connect with hyper textual information in the sense of nonsequential reading or non-computer-assisted disorder [9]. Then extends the concept of digital literacy as the ability to understand and use information from various digital sources; in other words the ability to read, write and relate to information using the technology and format that exist in its time [10]. Other authors use the term digital literacy to demonstrate the broad concept of linking together relevant literacy and competence-based literacy and communication technology skills, but emphasizing the more "soft" information evaluation capabilities and the shared knowledge sharing of understanding and attitude [9]

Digital literacy includes an understanding of the Web and search engines. Users understand that not all the information available on the Web has the same quality; so users can gradually recognize which websites are legitimate and reliable and which ones can not be trusted. In this digital literacy the user can choose a good user machine for his 
information needs, capable of effectively using the machine (e.g. "advanced search"

\section{B. Digital Literacy Components}

The digital literacy component consists of four parts as follows [9]:

1) Supporting milestones shall be:

- the literacy itself and

- literation of computers, information, and communications technology

2) Knowledge of the background is divided into:

- the world of information and

- nature of information resources

3) Competence in the form of:

- digital and non-digital format understanding creation and communication of digital information

- Evaluation of information

- Knowledge assembly

- Literacy information

- Location of media

4) Attitudes and perspectives.

This is what creates a link between the new concept of digital literacy and the old idea of literacy. Individuals are not sufficiently skilled and competent, but they must be based on a moral framework, associated with a person who is being cast. Of all the components of digital literacy, perhaps the most difficult to teach is the moral framework, but it is the strongest closeness to the term information in the Latin roots of informational means to form, describe.

Self-study and moral and social literacy are qualities that exist in a person with the motivation and mind to make the best use of the information. These three are the basis for understanding the importance of good information and information resources and communication channels and incentives to improve one's ability to a better level.

Moral literacy concerns the understanding that almost unlimited access to the Web is followed by the understanding that not all downloaded material is free from copyright.

The four components are considered to be a heavy dealing aimed at the information user. It's hard but it's a must if someone is involved and successful in today's information environment. In this case, especially digital literacy is a powerful tool to avoid problems and paradoxes in information behavior such as information overload, information anxiety, information evasion and the like [9].

\section{The main competencies of digital Literacy}

In digital literacy, the main competencies include [8]:

a) Understanding of digital and non-digital formats;

b) Creation and communication of digital information;

c) Evaluation of information;

d) assembling or assembling knowledge;

e) Information Literation and

f) Media Literacy

\section{Digital Literacy In Health}

Digital literacy in health is about the ability for everyone working in healthcare being able to learn, work and develop effectively in a digital workplace and society. Healthcare has traditionally been slow to adopt new digital tools and technologies that have significant potential to improve how we can provide the very best health and social care. By building and improving excellent literacy capabilities, the uptake and adoption of new digital tools and technologies can be dramatically improved. We can truly transform the way we practice clinically and provide care. The evidence suggests that people who have better digital literacy tend to have more positive attitudes and behaviors to adopting new technologies. With the fast pace of change in technologies that are developed to support and improve individual care and outcomes, everyone needs to be ready to support and lead on change and innovation [11].

Digital literacy domains: Becoming a digitally-literate person involves developing those function skills, plus attitudes, values and behaviors that can be categorized under the following domains:

- Digital identity, wellbeing, safety and security

- Communication, collaboration and participation

- Teaching, learning and personal/professional development

- Technical proficiency

- Information, data and media literacy

- Creation, innovation and scholarship.

\section{DISCUSSION}

\section{A. Background of Establishment of Vocational School of Health}

In relation to efforts to realize and follow up on the policy of advocating the repositioning of vocational education by 2020 suggests that the direction of school coaching and development is oriented towards the preparation of Human Resources (SDM) and the National Education Act of 2003 article 26, namely "Life Skills Education or lifeskills is education that provides personal skills, social skills, intellectual skills, and vocational skills for work or self-employment ". Where vocational can be a government asset in the framework of regional autonomy as well as preparing a workforce that has the competence and competitiveness to face the global era. As a consequence, as one of the educational institutions, it feels obliged to participate to equip their graduates with integrative life skills which combine generic and specific potentials to solve and overcome life problems. Life skills possessed by each graduate will include: Personal Knowledge, Rational Thinking Skills (Vocational Skills) and Vocational Skills (Vocational Skills). In order to realize the job seeker (open an independent business) with a program that is worth selling skills and is needed in the job market in the current era and the future.

Purpose of establishment of Vocational School of Health (SMK Kesehatan) are: 1) Preparing learners to become productive human being able to work independently to fill vacancies in the Business World / Industrial World as middle-level workers, in accordance with the competence in the program of choice, 2) Provide learners to be able to be a tenacious and persistent Health Analyst in competing, adaptable work environment and develop a professional attitude in the field of expertise of interest; 3) Conducting his profession in accordance with the moral of Pancasila and medical ethics and the ethics of the Health Laboratory; 4) performing laboratory tests on other referral health efforts; 5) Using and maintaining laboratory equipment used and knowing and repairing simple damage; 3) Conduct 
cooperation with other health workers; 6) To guide and nurture the health worker that is the responsibility; 7) Managing / leading the health laboratory in the first referral health effort; 7) Conducting laboratory administration; 8) Conducting health education in accordance with the field.

TABLE I. List of Vocational School of HeAlth in MaKasSAR CITY

\begin{tabular}{|c|l|l|l|}
\hline No & SCHOOL NAME & STATUS & \multicolumn{1}{c|}{ ADDRESS } \\
\hline 1 & $\begin{array}{l}\text { SMK Kesehatan } \\
\text { Plus Prima Mandiri } \\
\text { Sejahtera }\end{array}$ & Private & $\begin{array}{l}\text { Letjen Mappaodang } \\
\text { No.77, Makassar, } \\
\text { Tamalate, Kota } \\
\text { Makassar 90223 }\end{array}$ \\
\hline 2 & $\begin{array}{l}\text { SMK Kesehatan } \\
\text { YAPIKA }\end{array}$ & Private & $\begin{array}{l}\text { Jl. Sultan Alauddin No. } \\
\text { 98, Makassar, } \\
\text { Tamalate, Kota } \\
\text { Makassar }\end{array}$ \\
\hline 3 & $\begin{array}{l}\text { SMK Kesehatan } \\
\text { TNI AL }\end{array}$ & Private & $\begin{array}{l}\text { Jl. Yos Sudarso No. 38, } \\
\text { Tokaka, Ujung } \\
\text { Pandang, Kota } \\
\text { Makassar 90165 }\end{array}$ \\
\hline 4 & $\begin{array}{l}\text { SMK Kesehatan } \\
\text { TNI AL } \\
\text { MAKASSAR }\end{array}$ & Private & $\begin{array}{l}\text { Yos Sudarso No. 308, } \\
\text { Makassar, Ujung } \\
\text { Tanah, Kota Makassar } \\
\text { 90165 }\end{array}$ \\
\hline \multirow{2}{*}{5} & $\begin{array}{l}\text { SMK Kesehatan } \\
\text { Terpadu Mega } \\
\text { Rezky Makassar }\end{array}$ & Private & $\begin{array}{l}\text { Jl. Aroeppala } \\
\text { (Hertasning Baru), } \\
\text { Kassi - Kassi / } \\
\text { Makassar, Rappocini, } \\
\text { Kota Makassar 90232 }\end{array}$ \\
\hline & Tukada Kalsabila & Private & $\begin{array}{l}\text { JL. RSUP Faisal, } \\
\text { Rappocini, Rappocini, } \\
\text { Kota Makassar 00000 }\end{array}$ \\
\hline
\end{tabular}

\section{B. Literacy Movement in Vocational School}

Literacy education conducted in Indonesia is suspected not to develop the ability to think high, or HOTS (Higher Order Thinking Skills) which includes analytical, synthesis, evaluative, critical, imaginative, and creative. It is illustrated that in school, there is a dichotomy between learning to read (learning to read) and reading to learn (reading to learn). Reading activities have not received deep attention, especially in non-linguistic subjects. When studying the content of normative, adaptive and productive subjects, teachers use less text lessons to develop such high thinking skills [12].

Vocational students born in the era of information technology (digital natives) reading and writing are done in a way that is different from the generation before them. This skill should be accommodated in the classroom as well as in the Vocational School of Health (SMK Kesehatan) environment, so it should be maximally utilized to enhance cognitive, social, linguistic, visual, and spiritual skills. The vocational school's residents have no awareness and insight into librarianship. Teachers and principals still rely on the role of a librarian to drive the library, so that if a school does not have a librarian, the literacy activities in the vocational school are inhibited. In addition, the library (if available in $\mathrm{SMK}$ ), is still far from its function as a center of literacy activities in SMK. The library in the vocational school is not just a room to store books and multi-media equipment, but becomes a place to develop enjoyable literacy activities that are relevant to the learning activities in the classroom. In addition, Vocational School should also have a mading that is always full of writing students and other school residents.
Writings and other literacy works may also be uploaded on the Website / SMK page as virtual libraries.

In the learning phase at SMK of the Health Department, all subjects should use a variety of text (print / visual / digital) available in enrichment books or other information outside the textbook. Teachers are expected to be creative and proactive in searching for relevant learning references. Some of the benefits of literacy-based learning, among others [12]:

- improve the capacity of teachers and SMK education personnel in managing SMK resources to optimize learning according to their interests, potential learners, and local culture (In addition, teachers need to be examples of lifelong literacy and learners);

- literacy-based learning accommodates learners centered on learners who are encouraged to seek information through references, whether in the form of visual or digital print materials;

- reduce the cognitive burden of students of SMK in processing knowledge because the learning is presented through the books of enrichment of good quality and interesting and use the internet to access the subject matter in the teacher blog;

- citizens of SMK are accustomed to process information according to the usefulness, accuracy of content, appropriateness with age, and learning objectives, and are able to seek knowledge independently and can apply methods of learning appropriate to their interests and potentials (including studying distance learning materials when conducting work practices field); and

- Citizens of SMK will connect with the network of literacy communities, especially in implementing elearning culture in SMK, because literacy-based learning will require public participation as well as industry and business world.

Implementation of digital literacy program in SMK is expected to encourage students and other vocational residents in Supporting 21st Century Skills, as explained the use of computers can support 4C [13]. The Four of $21^{\text {st }}$ Century Skills, namely:

- Critical Thinker. To be a critical thinker, learners are encouraged to think critically and be able to solve problems by being tackled with learning problems, being asked questions, and trying to solve problems by searching for information through the internet.

- Communicator. In preparing a workforce that is able to become a communicator, then learners are trained to understand and communicate ideas. After understanding what is learned, learners are encouraged to share ideas that have become ideas as to what they have gained through literacy activities.

- Collaborator. The ability to work together is necessary in doing work with others. Therefore, with digital literacy learners are trained to work with others, other groups, other fields, by sharing information and experiences through computer media. 
- Creator.SMK graduates are not only prepared to become formal workers who will work for others, but also prepared to be entrepreneurs. Therefore, the ability to be a creator is necessary to produce work with high quality. The work can be in the form of goods, services, creations, high-powered, practical, simple and easy to use, etc.

In implementing the School Literacy Movement (GLS), various interventions and habits for families, schools, and communities were implemented. Intervention is done with the application of Permendikbud No. 23 of 2015 on the Growing of Character, conducted through various trainings and seminars; while habituation is done by demonstrating various exemplary examples from principals, teachers, and other school residents as a first step of habituation. The Literacy Movement in the Vocational School covers a variety of practical activities and can be implemented in SMK, one of which is the Provision of Electronic Lesson Materials through: 1) the implementation of teaching material compilation activities; andUpload teaching materials to the SMK Education Directorate's page and school page.

\section{Learning Innovation In The Field Of Health}

One of the learning media that can be used through digital literacy is through the utilization of Android-based applications that E-Health. SMK Health in Indonesia has great potential to apply e-health because with electronic media can reach the islands in Indonesia faster than nonelectronic media although there are still areas that do not have electricity and internet. E-Health technologies that are likely to be applied are $\mathrm{m}$-health and telemedicine, as the level of mobile phone ownership is higher than the level of internet access users [14].

The main source of health data and information is medical record, medical record is a description both written and recorded about identity, anamnesis, physical determination, laboratory, diagnosis of all services and medical action given to patients and treatment both hospitalized, outpatient or who received emergency services [15]. Considering the importance of medical record data, it is necessary to integrate with ICT by making Information System of medical record data, where computer-based system is better than the old system [16].

Learning by using E-Health application obtained benefits include:

- Creation of an E-Health learning device that can facilitate the general public and hospital patients, especially in controlling health conditions based on information technology;

- With the E-Health software, the doctor handling the patient can access the medical record information quickly anywhere and anytime online;

- With the hardware E-Health, then all our body conditions that have been done check-up (eg Measuring blood pressure, measure cholesterol with the tool) then can be consulted to the doctor either through the website, or social networking media. In this section will be made mobile-based applications (HP Android), and SMS Gateway to make automatic system work with a single button;
- With e-Health learning tools, communities benefit from health education to prevent disease and improve the quality of health services and reduce health costs.

\section{Application Design}

E-health learning media is an Andoid-based Application. As we know that Android is one of the most widely used mobile platform in the world with operating system based on open source. E-Health or Electronic Health is the use of information and communication technologies including electronics, telecommunications, computers and informatics to process various types of medical information, to perform clinical services (diagnosis or therapy), administration and education. The following will feature an Android-based EHealth learning feature

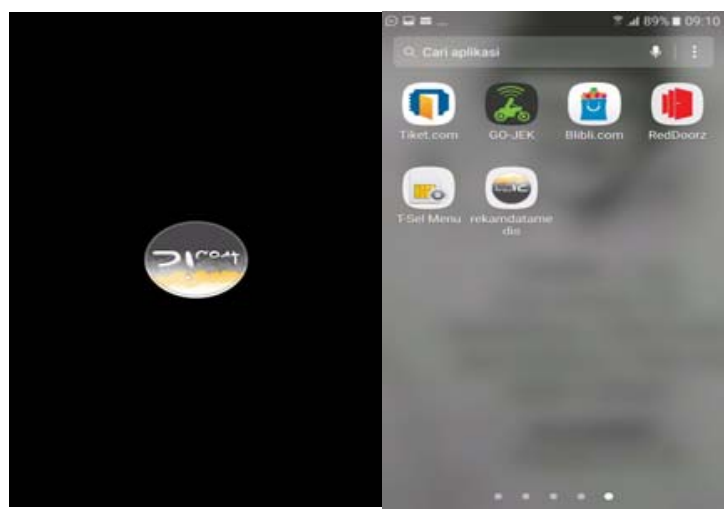

Fig. 1. Preview \& Icons

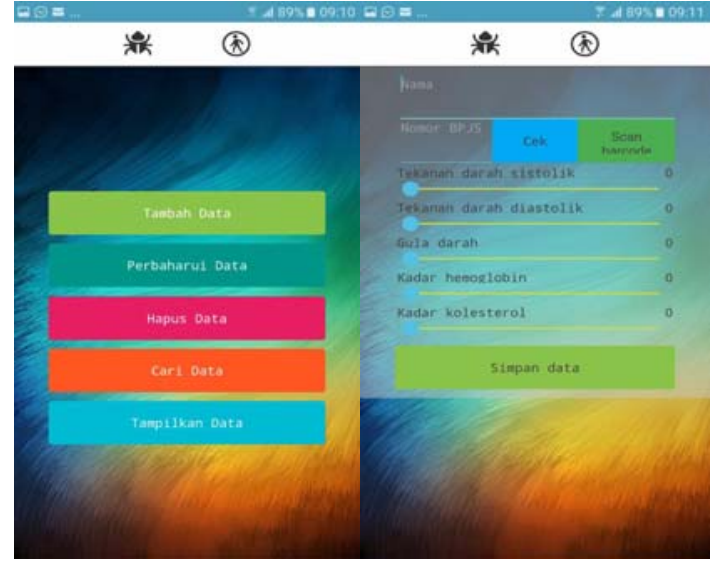

Fig. 2. Main Menu

The e-health application is appropriate and necessary for health professionals and authorities in the health care system (PRALAMPITA, 2017). Like a real example that can be done e-health. First, the medical record. The medical record is the patient's right to know the health status or illness. The medical record keeps a patient's complete history of health, an accurate diagnosis that relies heavily on the patient's historical medical records. Ideally, everyone has a historical longitudinal medical record, which keeps a record of health from birth. This medical record stores health information, both illnesses and health records, since the birth of a patient. This medical information will greatly help a doctor know the status or health condition of a patient. In Indonesia, longitudinal medical records are still the responsibility of the patient, as Indonesia has no regulation on standards for the 
management and storage of medical records. This of course makes it difficult for patients to have a complete historical medical record. E-health can manage it. Second, is the management of historical data on patient health, where most hospitals and health agencies still retain health data text format. While the patient's medical image data has not been integrated with the patient's historical data and kept independent. The main reasons for separated storage between textual data and medical images are the limited storage capacity and telecommunication bandwidth required if the data has to be accessed through the network. Therefore, the development of a system capable of integrating medical image data with patient data and supporting the exchange of text data and medical images between various health care providers, especially for hospitals is through the development of E-Health software that can also be used as a medium of learning in SMK Kesehatan .
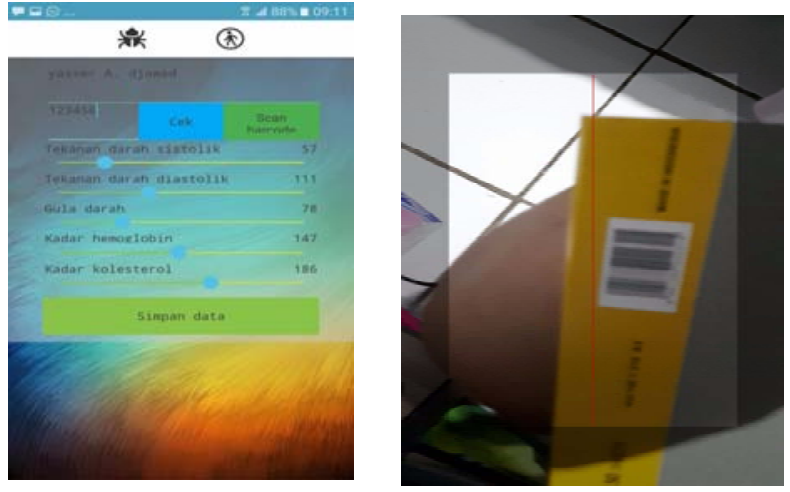

Fig. 3. Example Data Scan \& Use Barcode Scan

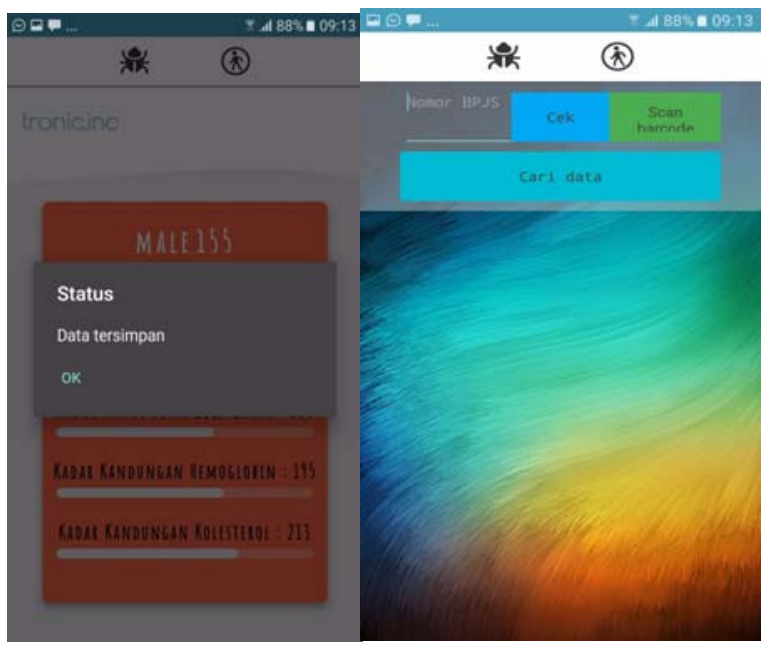

Fig. 4. Results Display Data \& Display Search patient data

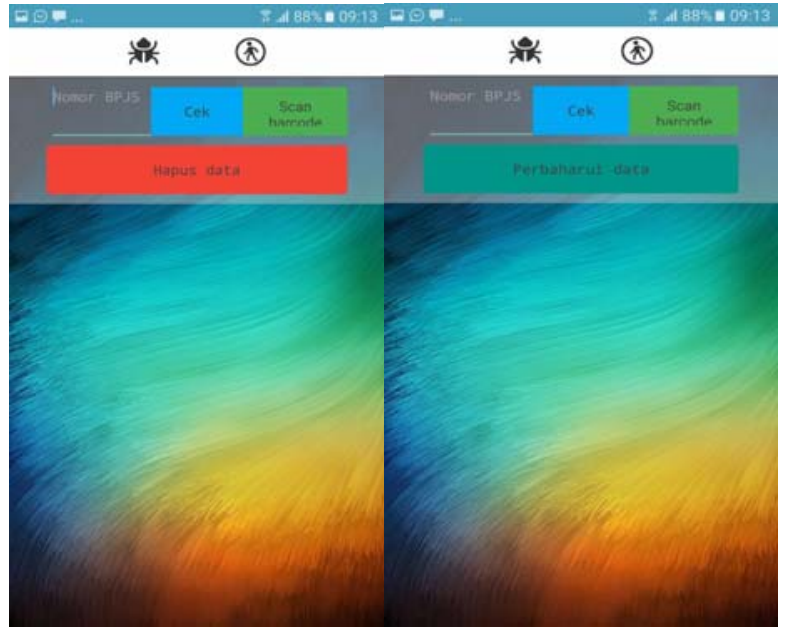

Fig. 5. Display (Delete patient data\&Update Patient Data

To find out the results of media assessment can be seen the following Table II.

TABLE 2. ASSESSMENT OF DISPLAY ASPECTS BY MEDIA EXPERTS

\begin{tabular}{|l|l|c|c|}
\hline \multirow{2}{*}{ NO } & \multicolumn{2}{|c|}{ ASPECT } & \multicolumn{2}{c|}{ Total Score } \\
\cline { 3 - 4 } & & average score & description \\
\hline A & Text & 4,48 & Very Good \\
\hline B & Language & 4,60 & Very Good \\
\hline C & Figure & 4,32 & Very Good \\
\hline D & Colors & 4,43 & Very Good \\
\hline E & Lay Out & 4,53 & Very Good \\
\hline F & Button & 4,33 & Very Good \\
\hline G & Resolution & 4,60 & Very Good \\
\hline $\begin{array}{l}\text { OVERALL } \\
\text { RECORDS }\end{array}$ & $\mathbf{4 , 4 7}$ & Very Good \\
\hline
\end{tabular}

Results of Media Assessment obtained average score 4.47 (Very Good).

\section{CONCLUSSION}

Vocational School of Health is an education provider institution in the field of health feels obliged to participate equip their graduates with life skills (life skills) in integrative, which combine generic and specific potency, to solve and overcome life problem. Life skills possessed by each graduate will include: Personal Knowledge, Rational Thinking Skills (Vocational Skills) and Vocational Skills (Vocational Skills). Implementation of digital literacy in SMK is expected to encourage students and other vocational residents in supporting 21 st Century Skills Century Skills, namely: 1) Critical Thinker; 2) Communicator; 3) Collaborator; 4) Creator. One of the learning media that can be used through digital literacy is through the utilization of Android-based applications. Results of Media Assessment obtained average score 4.47 (Very Good).

\section{ACKNOWLEDGMENT}

Acknowledgments are addressed to the Ministry of Research, Technology and Higher Education which has provided an opportunity to conduct this research. 


\section{REFERENCE}

[1] Danang. Implementasi literasi digital dalam gerakan literasi sekolah.Konferensi Bahasa dan Sastra II International Conference on Language, Literature, and Teaching. 2017

[2] Nasrullah. Rulie, LITERASI DIGITAL. Kementerian Pendidikan dan Kebudayaan Jakarta 2017.

[3] Wardiman Djojonegoro. Pengembangan Sumber Daya Manusia Melalui SMK. Jakarta: Jayakarta Agung Offset. (1998).

[4] Raymond R Tjandrawinata. Industri 4.0: Revolusi Industri Abad Ini Dan Pengaruhnya Pada Bidang Kesehatan Dan Bioteknologi. 2016.

[5] Ibrahim, Inovasi Pendidikan, Jakarta: Depdikbud Ditjen Dikti PPLPTK.(1988)

[6] Tubagus Rangga Efarasti. Pengertian dan Tujuan Inovasi Pendidikan.diambil Online Tanggal 20 Maret 2018. alamathttps://indonesiamengajar.org/forum/discussion/116/pengertian -dan-tujuan-inovasi-pendidikan/p1

[7] Kemendikbud. PanduanGerakan Literasi Sekolah di Sekolah Dasar. Jakarta:Direktorat Jenderal Pendidikan Dasar dan Menengah Kementerian PendidikandanKebudayaan Republik Indonesia.2016.

[8] Davis, C H , \& Shaw, D (Eds) Introduction to information science and technology Medford, NJ: Information Today. (2011)

[9] Bawden, D. "Informa on and Digital Literacies: A Review of Concepts“ in Journal of Documenta on, 57(2), 218-259.2001.

[10] Gilster, P. Digital Literacy. Wiley Computer Publishing, New York.(1997),

[11] Janet Davies. Improving Digital Literacy. Royal College of Nursing.2016

[12] Nurwidyani, dkk. Panduan Gerakan Literasi Sekolah Di Sekolah Menengah Kejuruan Direktorat Pembinaan Sekolah Menengah Kejuruan Direktorat Jenderal Pendidikan Dasar Dan Menengah Kementerian Pendidikan Dan Kebudayaan Tahun 2016

[13] D Zoraini, Wati Abas. "What Is it About Learning and teaching in The $21^{\text {st }}$ Century/ChangesEmployerWant,Graduate."CenterforLearning,teaching andCuricullumUniversitas Siswa Bangsa.2014.

[14] Edy Kristianto. E-HEALTH DI INDONESIA (E-Health in Indonesia) Jurnal Teknik dan Ilmu Komputer. Vol. 02 No. 06, Apr - Jun 2013

[15] Sharon Gondodiputro. Rekam Medis Dan Sistem Informasi Kesehatan Di Pelayanan Kesehatan Primer (Puskesmas).Ilmu Kesehatan Masyarakat Fakultas Kedokteran Universitas Padjadjaran Bandung 2007.

[16] Eti Murdani. Pengembangan Sistem Informasi Rekam Medis Rawat Jalan Untuk Mendukung Evaluasi Pelayanan Di Rsu Bina Kasih Ambarawa. Program Pascasarjana Universitas Diponegoro Semarang.2007. 